\title{
Shell architecture and its relation to shell occupation by the hermit crab Clibanarius antillensis under different wave action conditions
}

\author{
ARACELI ARGÜELLES ${ }^{1}$, FERNANDO ÁLVAREZ ${ }^{2}$ and GUILLERMINA ALCARAZ ${ }^{1}$ \\ ${ }^{1}$ Laboratorio de Ecofisiología, Departamento de Ecología y Recursos Naturales, Facultad de Ciencias, Universidad Na- \\ cional Autónoma de México, México 04510, D.F., México. E-mail: alcaraz@ciencias.unam.mx \\ ${ }^{2}$ Colección Nacional de Crustáceos, Instituto de Biología, Universidad Nacional Autónoma de México, Apartado Postal \\ 70-153, México 04510, D.F., México.
}

\begin{abstract}
SUMMARY: We studied the intertidal hermit crab Clibanarius antillensis at Montepio Beach, Veracruz, Mexico, to determine whether architecture and weight of occupied shells varied with the degree of exposure to wave action. Data on shell use were obtained from 30-m transects perpendicular to the shoreline. The gastropod shells species used by C. antillensis were classified into four groups according to their morphology: neritiform, conical, turriculate, and turbinate. Neither the size nor the weight of hermit crabs varied along transects. A pattern showing differential use of shell type according to water velocity was detected. Neritiform and turriculate shells were the least occupied, and their abundance decreased with increasing water velocities. Conical and turbinate shells were the most used and their presence increased with increasing water velocities. Turbinate and conical shells are heavier and have a higher weight/exposed-area ratio than neritiform and turriculate shells, so using them at higher energy sites seems to be more advantageous than using turriculate shells. The pattern that emerges is one in which $C$. antillensis occupy different shells along the intertidal transect, probably due to the advantages that different shells may bring, such as minimising drag and the risk of dislodgement.
\end{abstract}

Keywords: hermit crabs, hydrodynamics, Clibanarius antillensis, gastropod shell, intertidal, rocky shore.

RESUMEN: ARQUITECTURA Y OCUPACIÓN DE CONCHAS POR EL CANGREJO ERMITAÑO CLIBANARIUS ANTILLENSIS BAJO DIFERENTES CONDICIONES DE OLEAJE. - Estudiamos al cangrejo ermitaño intermareal Clibanarius antillensis en Montepío, Veracruz, México, para determinar si la arquitectura y tamaño de la conchas utilizadas variaba con respecto al grado de exposición al oleaje. Los datos provienen de transectos de $30 \mathrm{~m}$ perpendiculares a la costa. Las conchas utilizadas por $C$. antillensis se clasificaron en cuatro grupos: neritiformes, cónicas, turriculadas y turbinadas. La talla y el peso de los cangrejos no variaron en los transectos. Se detectó un patrón de uso diferencial del tipo de concha de acuerdo a la velocidad de la corriente. Las conchas neritiformes y turriculadas fueron menos utilizadas y su abundancia decreció con el aumento en la velocidad de la corriente. Las conchas cónicas y turbinadas fueron más usadas y su presencia se incrementó con el aumento en la velocidad de la corriente. Estas conchas fueron más pesadas y tuvieron un índice de peso/área expuesta alto en relación a las neritiformes y turriculadas; su uso en sitios con alta energía parece ventajoso sobre las turriculadas. Se sugiere que $C$. antillensis ocupa diferentes conchas en el transecto intermareal, debido a las ventajas que obtiene de diferentes conchas, como minimizar el arrastre y reducir el riesgo de desprendimiento.

Palabras clave: cangrejos ermitaños, hidrodinámica, Clibanarius antillensis, gasterópodos, intermareal, playa rocosa.

\section{INTRODUCTION}

Hermit crabs depend on fitting properly in gastropod shells for protection from predators, increased mating success and successful reproduction (Childress, 1972; Hazlett, 1981, 1989). They show a preference for certain types of shell that bring them these advantages and maximise their fitness (Markham, 
1968). Shell availability is the main limiting resource, and they cannot obtain shells from living gastropods in natural conditions, so they have to find available shells or fight intra- and interspecifically to get the appropriate shell (Childress, 1972; Fotheringham, 1976; Hazlett, 1980).

Hermit crabs do not occupy shells randomly, but select shells of the appropriate size (Lively, 1989). The proper shell depends on the size and morphological characteristics of the crab (Scully, 1979; Côté et al., 1998) and previous shell experience (Alcaraz and Kruesi, 2009), but also on the environmental conditions, such as wave action. In the intertidal zone, hydrodynamic stress is an important factor determining shell use and preference. Scully (1979) explained shell preference in Pagurus longicarpus on the basis of differences in wave action between two sites. Hahn (1998) found that the hermit crab, Calcinus seurati, collected at high flow sites occupied heavier shells than those inhabiting still water sites; similarly, in controlled conditions, hermit crabs preferred heavier shells in flow conditions than in still water, suggesting that shell weight is important in shell preference. Similar results have been reported for Calcinus gaimardii and C. elegans (Hahn, 1998). Garcia and Mantelatto (2001) found experimentally that Calcinus tibicen selected the heavier shells and described this result as advantageous for an intertidal organism subjected to strong wave action. However, Floeter et al. (2000) showed experimentally that Calcinus tibicen and Clibanarius antillensis from southeastern Brazil selected shells based first on shell internal volume rather than weight.

The upper intertidal is characterised by rapid and strong changes in temperature, salinity, air exposure, $\mathrm{pH}$, dissolved oxygen and food supply that occur on a daily basis due to the movement of the tides. Additionally, this zone is influenced by the physical stress induced by waves, which plays an important role in determining the distribution of species and populations (Connell, 1972; Bertness, 1981a; Denny and Gaines, 1990). Intertidal organisms have to cope with directionally unpredictable water flows of variable intensity (wave-swept flow), and are exposed to flow acceleration and drag and lift forces (Vogel, 1988; Denny et al., 1985). Total drag depends on water velocity and is positively correlated with the projected area in the direction of the flow; to a lesser degree it is negatively correlated with the animal's mass (Vogel, 1988; Bell and Gosline, 1997). Thus, at any given velocity, the surface area exposed to the flow and the shell weight should be important factors in determining the ability of hermit crabs to remain attached to the substratum. Hermit crabs occupying heavy shells with a small exposed area could be expected to obtain greater benefits at sites with high wave action than individuals occupying lighter shells with a larger exposed area. Some studies have reported that heavier shells bring advantages over lighter ones at sites with high wave influence (Hahn, 1998). Additionally, it has been mentioned that shell architecture is one of the most important factors linked to the risk of dislodgement from the substrate by wave action (Reese, 1962; Conover, 1978; Hahn, 1998); however the information about this aspect is very limited.

Previous studies in Montepio have shown that $C$. antillensis inhabits shells of at least 41 different species of gastropods (Argüelles, 2004), which to our knowledge represents the highest diversity of shells used by any hermit crab population. The high diversity of shells available at Montepio Beach for C. antillensis together with the presence of a well-defined hydrodynamic gradient along the intertidal make it possible to explore under natural circumstances the importance of shell weight and morphology as factors that can influence hermit crab occupation. The hypothesis that we tested in this study is that the use of different shells along the intertidal transect will depend on their shape and weight, two characteristics that can be used to cope with the hydrodynamic forces imposed by wave action. We expected to find an increasing number of crabs occupying shells with a greater weight/exposed surface area ratio at sites with greater wave action influence.

\section{MATERIALS AND METHODS}

The study was conducted in a rocky intertidal zone at Montepio Beach, Veracruz, Mexico (18 $38^{\circ} 34^{\prime}$ 'N, $\left.95^{\circ} 05^{\prime} 50^{\prime \prime} \mathrm{W}\right)$. The study site is an ancient lava flow that extends $60 \mathrm{~m}$ from the shore to a depth of 1.5 $\mathrm{m}$. Wave action increases from the shore, where some tidal pools collect, to the completely exposed end of the outcrop (Hernández and Alvarez, 2007). The study was conducted in July 2002, due to the high abundance of hermit crabs during this season (Hernández and Alvarez, 2007). The tidal cycle in the region is diurnal with a maximum variation of 68 $\mathrm{cm}$ in July (Servicio Mareográfico Nacional). 
Samples were taken on three consecutive days using $30 \mathrm{~m}$ transects placed randomly, running perpendicular to the shoreline, with $1 \mathrm{~m}^{2}$ quadrats positioned along the line every $3 \mathrm{~m}$. A total of 10 transects with 10 quadrats each were sampled. Each quadrat was placed covering $0.5 \mathrm{~m}^{2}$ on each side of the line. Sampling sites along the transect were grouped according to the intensity of wave action, estimated as the maximum water velocity reached by the waves in a 5-minute period. The maximum water velocity measured in each quadrat was used as an indicator of wave action since it determines whether an animal can remain in a given position or will be dislodged (Carrington and Denny, 1994).

Within each quadrat all rocks and crevices were searched for hermit crabs, and every hermit crab and vacant gastropod shell was collected by hand. Sampling was conducted during low tide, in July 2002. At each collecting site the type of sediment, degree of air exposure, presence/absence of algae, and bottom configuration were recorded. The depth at each site was determined as the mean of the lowest and highest water level during 5 minutes. The minimum and maximum water velocities produced by the waves in a 5-minute period were recorded for each quadrat with a flow meter (Global Water, precision $\pm 0.1 \mathrm{~cm} \mathrm{~s}^{-1}$ ). The maximum water velocity was used as a measurement of the hydrodynamic wave action. Measurements of the water velocity were taken as close to the bottom as possible; the hydrodynamic stress was high far from the coast and weak towards the shoreline. The lowest water velocity was zero in isolated pools, while the highest was $11 \mathrm{~cm} \mathrm{~s}^{-1}$. Water velocities were grouped into five categories as follows: $0,1.5$ (range 1.2 to 2.2), 2.8 (range 2.3 to 3.3 ), 3.8 (range 3.4 to 4.4 ), and $10.5 \mathrm{~cm} \mathrm{~s}^{-1}$ (range 10.0 to 11.0 ).

Field data were analysed for size distribution of males and females and differences in shell use along the transects, grouping the collecting sites according to the maximum water velocity recorded. All unoccupied and occupied shells were returned to the laboratory. Hermit crabs were removed from their shells by heating the apex of the shell with a flame. The species of the hermit crabs was confirmed (Provenzano, 1959; Abele and Kim, 1986) and the organisms were sexed according to the gonopore position. Hermit crabs were dried with a paper towel to remove the excess water and weighed to the nearest $0.01 \mathrm{~g}$. They were measured for shield length (the distance between the rostrum tip and posterior end of the cervical suture) and largest chela dimensions.
The shells were measured for height, as the distance from the siphonal canal to the apex, width (at the widest point), aperture length (including siphonal canal) and aperture width. All measurements were taken using digital callipers. Empty shells were cleaned and dried in an oven $\left(12 \mathrm{~h}\right.$ at $\left.60^{\circ} \mathrm{C}\right)$ before they were weighed using an analytical balance (Sartorius, $\pm 0.01 \mathrm{~g}$ ). The gastropod shells were identified to genus or species (Abbott and Morris, 1995; Wye, 2000).

Shells were grouped into four categories according to their morphology (Andrews, 1971; GarcíaCubas et al., 1994): a) neritiform or globose, with a very round shell and sunken spire (e.g. members of the Neritidae) ; b) narrowly conical, having approximately the shape of a cone, tapering evenly from a wide, circular base to a point, markedly higher than wider (e.g. Columbella spp.); c) turriculate, having the form of a turret or tower-shaped, with spire whorls regularly stepped in an outline forming a long spire with somewhat shouldered whorls (e.g. Terebra spp.); and d) turbinate, or turban-shaped, with a broadly conical spire and convex base, flattened at the apex and abruptly tapered at the base, with a large and rounded aperture opening more to the side (e.g. Astrea spp.).

To confirm whether the observed morphological pattern corresponded to significant differences among the four groups of shells, all the different species used by $C$. antillensis were photographed in the field with a digital camera, using a ruler as a scale. The maximum area of 131 shells of the different types was estimated from the digitised images using the "Image J" program for Windows (http:// rsb.info.nih.gov/ij/). The maximum exposed surface area of the shell does not necessarily reflect the area over which wave forces are most frequently applied because of the multidirectional flows that are present in the intertidal. However, the maximum surface area exposed to water flow is the most important component of the total drag generated by waves (García-March et al., 2007). The weight/maximumexposed-area ratio was estimated for all the shell species, and significant differences among the four morphological groups were obtained $\left(\mathrm{F}_{(3,128)}=589\right.$, $\mathrm{p}<0.001$; Fig. 1).

\section{Statistics}

Water velocity among quadrats was compared using the 10 maximum velocities recorded during 


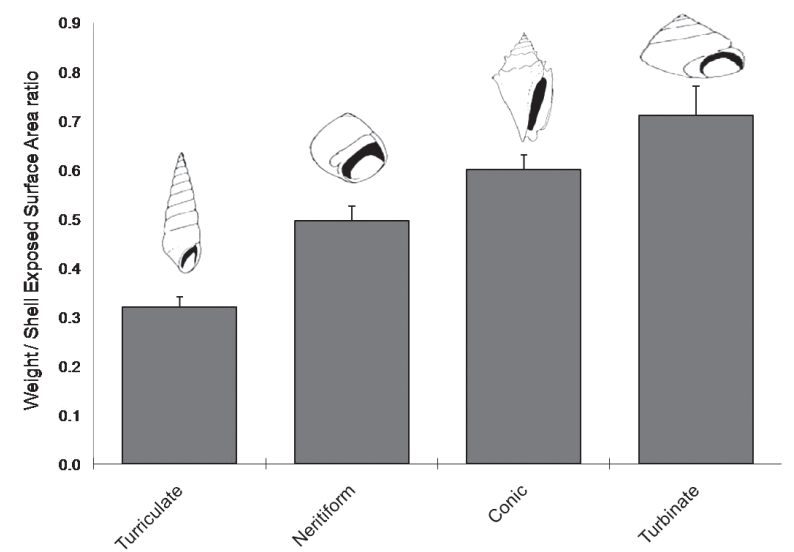

FIG. 1. - Weight / Exposed Surface Area ratio of the different types of shells occupied by the hermit crabs in Montepio. Mean values and standard errors are shown.

5 minutes in each quadrat through a MANOVA. Linear regressions were performed to estimate the relationship between different measurements of crabs vs. shells (shield length, chela dimensions and weight for crabs; height, width and weight for shells) that describe hermit crab size and type of shell occupied. Deviations from a 1:1 sex ratio, and differences in male and female (non-ovigerous and ovigerous) abundance along transects were tested with chisquare analyses. Differences in size between sexes and the distribution of crabs and shell weights along transects were evaluated through a one-way ANOVA; Tukey tests were used to test for significant differences among groups. The shell use pattern under different intensities of wave action along transects was analysed in relation to water velocity using a chi-square test.

\section{RESULTS}

Temperature, presence of algae, type of sediment, and salinity were similar along transects $(P<0.05)$. However, water velocity varied drastically among the collecting sites. Three other hermit crab species were collected together with Clibanarius antillensis, which was the most abundant species in Montepio, representing $92.1 \%$ of the 190 hermit crabs collected; Clibanarius tricolor, Calcinus tibicen, and Paguristes grayi were less abundant with 7, 4, and 4 individuals, respectively, and were not included in the study. Hermit crab weight $\left(\mathrm{W}_{\mathrm{HC}}\right)$ and shield length (SL) were positively correlated $\left(\mathrm{SL}=3.88 \mathrm{~W}_{\mathrm{HC}}\right.$ $\left.+0.26 ; R^{2}=0.78 ; p<0.01\right)$. The SL and shell weight $\left(\mathrm{W}_{\text {SHELL) }}\right.$ were the measurements that best explained

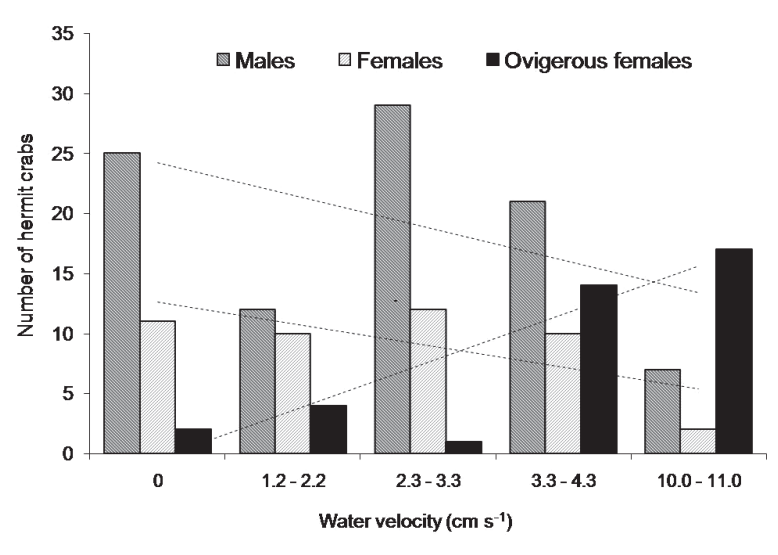

FIG. 2. - Number of males, females and ovigerous females along the intertidal transect. Dashed lines show the tendency of each sex in the water velocity ranges.

the relationship between crab size and shell occupied $\left(\mathrm{W}_{\text {SHELL }}=0.29 \mathrm{LC}-0.76 ; \mathrm{R}^{2}=0.67 ; P<0.01\right)$; thus, these were the crab and shell measurements used for further analysis.

The gastropod species included in the neritiform group were Nerita fulgurans, Bulla striata, and Polinices hepaticus; shells grouped as conical were Cantharus tinctus, Columbella mercatoria, Morula nodulosa, Engina turbinella, Latirus virginensis, Leucozonia nassa, Strombus alatus, Thais haemastoma biserialis and T. haemastoma floridiana; shells grouped as turriculate were Cerithium lutosum, Epitonium lamellosum, Odostomia sp., Terebra sallea$n a$, and $T$. cinerea; and shells grouped as turbinate were Astrea sp., Calliostoma sp., Modulus modulus, and Tegula fasciata. None of the unoccupied shells found (Vermicularia sp. and Tonna galea) were of species used by $C$. antillensis in the field (Argüelles, 2004).

The sex ratio considering all the crabs collected in the field was 1:1 $\left(\chi^{2}=0.007: P=0.93\right)$. However, the abundance of both sexes varied along transects. Males were more abundant closer to the shoreline $\left(\chi^{2}=32.1 ; P<0.001\right)$, ovigerous females were more abundant away from the shoreline $\left(\chi^{2}=31.7\right.$; $P<0.001)$, and non-ovigerous females were homogenously distributed along transects $\left(\chi^{2}=7.5, P=0.11\right.$; Fig. 2).

Clibanarius antillensis showed sexual dimorphism with respect to size, adult males being larger than females. The mean weight of males, females, and ovigerous females was significantly different $\left(\mathrm{F}_{(2,173)}=4.31, P=0.02\right)$. Non-significant differences were found between the weight of the ovigerous and non-ovigerous females (Tukey test, $P=0.89$ ); but 


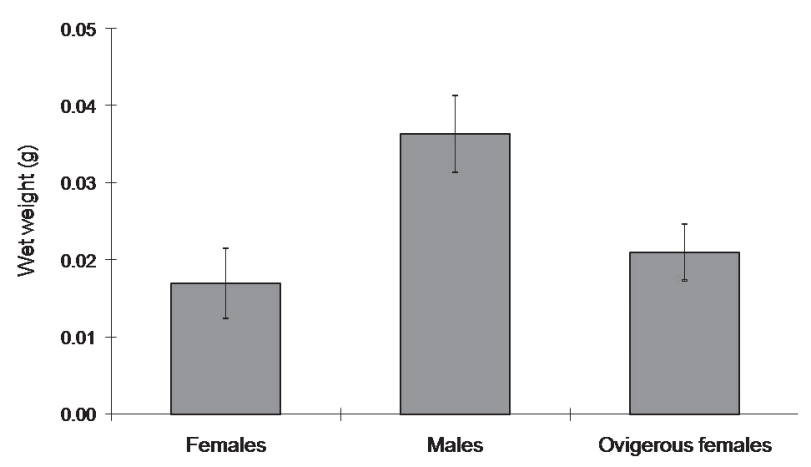

FIG. 3. - Overall wet weight of males, females, and ovigerous females occupying different types of shells all along the intertidal. Mean and standard errors are shown.

males were $53 \%$ heavier than females (Tukey test, $P=0.02$, Fig. 3).

The mean weight of each of the different types of shells was significantly different $\left(\mathrm{F}_{(3,172)}=15.0\right.$, $P<0.001$ ); turriculate shells were $77 \%, 60 \%$, and $50 \%$ lighter than shells grouped as neritiform, conical, and turbinate, respectively (Tukey test; $P<0.01$, $P<0.01$, and $P=0.04$, respectively). Non-significant differences were found between the weight of the neritiform, conical, and turbinate shells (Tukey, $P>0.05)$. The weight of neritiform, conical, and turriculate shells was similar among the different water velocity levels (neritiform: $P=0.26$; conical: $P=0.83$, and turriculate: $P=0.60$ ). However, turbinate shells were heavier at the higher velocity levels $(P<0.004)$. The weight/exposed surface area ratio showed significant differences between the four shell types $\left(\mathrm{F}_{(3.128)}=589, P<0.001\right)$. Turbinate shells showed the highest weight/exposed area ratio $(P<0.01)$, followed by conic $(\mathrm{P}<0.05)$, neritiform $(\mathrm{P}<0.05)$, and turriculate shells $(P<0.01)$.

Similarly, the weight of hermit crabs varied depending on the shell occupied $\left(\mathrm{F}_{(3,172)}=4.41\right.$, $P<0.01)$; hermit crabs occupying turriculate shells were lighter than ones occupying conical shells (Tukey-test, $P<0.02$ ); non-significant differences were found between the weight of crabs occupying other types of shells (Tukey, $P>0.05$ ). The weight and shield length of hermit crabs did not vary along transects $\left(\mathrm{F}_{(3,172)}=1.80, P=0.33\right)$.

The distribution of the shell types occupied by $C$. antillensis varied along transects $\left(\chi^{2}=26.6 ; P<0.001\right.$; Fig. 4), with conical shells being the most occupied. The abundance of the conical shells occupied by hermit crabs increased with the increase in water velocity $\left(\chi^{2}=10.41 ; P<0.01\right)$. Similarly, hermit crabs occupying turbinate shells were more abundant in the

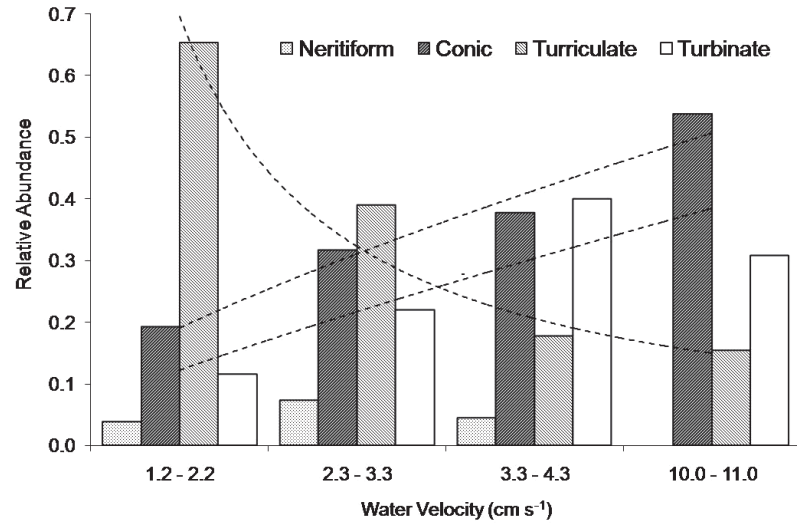

FIG. 4. - Distribution of types of shells occupied by $C$. antillensis in Montepio beach. Dashed lines show the tendency of the relative abundance in the water velocity ranges.

higher ranges of water velocity $\left(\chi^{2}=13.19 ; P<0.001\right.$; Fig. 4), while the abundance of occupied turriculate shells decreased with the increase of water velocity $\left(\chi^{2}=17.01 ; P<0.01\right)$. Neritiform shells were the least occupied; their abundance did not change along the water velocity gradient $\left(\chi^{2}=2.42 ; P=0.30\right)$.

\section{DISCUSSION}

A limiting factor is one that controls processes, such as individual growth, population size and/or distribution. It is well known that shells are important limiting resources for hermit crab populations (Childress, 1972; Vance, 1972a; Fotheringham, 1976). Additionally, physical factors in the more exposed zone of the intertidal, such as high temperatures, desiccation and wave action, may also restrict the distribution of hermit crabs (Bollay, 1964; Reese, 1969; Vance, 1972b). Particularly, breaking waves can impose large drag and lift forces, challenging the crab's ability to remain attached to the substrate (Lau and Martinez, 2003). Variations in substrate and sediment type and in salinity along transects were minimal, while wave action varied greatly among the different sites.

The presence of the organisms in the intertidal depends on several factors, including their ability to avoid being dislodged from the substrate by the flow of water (Lau and Martinez, 2003). For many intertidal animals, the resistance to dislodgement is positively associated with animal size (Lau and Martinez, 2003); however, the friction drag increases with size as a result of the increase in the exposed surface area (García-March et al., 2007). In this study, hermit 
crab size (weight and shield length) did not vary significantly along the transects, but the shell occupation pattern was significantly different among the sites with different degrees of exposure. Turbinate and conical shells were more frequently used at sites with higher wave influence, while turriculate shells where less used in these sites. Turbinate shells were the heaviest, and turbinate and conical shells had a higher weight/exposed-area ratio than neritiform and turriculate shells, so using turbinate and conical shells at higher energy sites seems to be more advantageous than using the the lighter turriculate shells with a lower weight/exposed surface area ratio.

The same pattern of a higher occupancy of heavier shells at sites subjected to higher levels of wave action has been reported for Calcinus seurati, also suggesting that heavier shells provide an advantage for the crab at sites where the risk of dislodgement is higher (Hahn, 1998). However, only different sizes of Thais spp. shells were tested in that study, and no conclusions about shell morphology could be drawn.

An alternative explanation for the shell occupancy pattern found in Montepio can be based on the gastropod distribution along the intertidal, which could determine the pattern of shell occupancy, as reported by Raimondi and Lively (1986). However, several gastropod species occupied by $C$. antillensis in Montepio are not inhabitants of rocky pools systems; instead some are typical inhabitants of Thalassia beds such as Cerithium litteratum and Modulus modulus (García-Cubas et al., 1994; Prieto et al., 2003), of seagrass such as Tegula fasciata (Pérez, 1997; Frankovich and Zieman, 2005) and Odostomia impressa, which is a parasite of oysters (Wilson et al., 1991). Hermit crabs occupying shells of gastropods that do not inhabit their habitat has also been reported for Clibanarius panamensis (Borjesson and Szelistowski, 1998).

Shell architecture is one of the most important factors linked to the risk of dislodgement from the substrate by wave action (Reese, 1962; Conover, 1978). The higher occupancy of conical and turbinate shells in the more exposed areas was associated with the use of these types of shells by ovigerous females. At the sites with the highest wave action, $70 \%$ of hermit crabs were ovigerous females, of which $78 \%$ occupied conical and turbinate shells. The results suggest that enduring in the more exposed portion of the intertidal while occupying conical and turbinate shells might bring advantages for ovigerous females, such as a better aeration of the egg mass and/or a more efficient dispersal of hatching larvae. Even when the risk of dislodgement is higher at these sites, the risk of predation may be lower (Bertness, 1981b; Palmer, 1988; Denny and Gaines, 1990; Powers and Kittinger, 2002).

The shell use pattern along the intertidal indicates that hermit crabs have to actively seek and compete for shells of the appropriate type according to the conditions of the site. Or else, since hermit crabs are capable of moving rapidly long distances along the intertidal zone (Hazlett, 1981), they could continually move to sites where the shells they have and the prevailing hydrodynamic conditions combine to minimise the risk of dislodgement. Therefore, it is likely that shell preference is a behavioural adaptation tuned by hydrodynamic conditions, as has been suggested for Clibanarius vittatus (Rittschof et al., 1995).

Although it is well established that hermit crabs use shells as protection against desiccation, osmotic stress and predation (Garcia and Mantelatto, 2001), the effect of shell type under changing hydrodynamic conditions has been only superficially studied. Our results show that occupancy of different types and sizes of shells depends on the intensity of wave action. However, our data do not demonstrate the adaptive consequences of shell occupancy, nor do they distinguish whether the crabs get the appropriate shell depending on the intertidal zone they inhabit, or whether they move to different zones along the intertidal gradient depending on the shell they already occupy.

Tropical hermit crab populations can be found occupying a great diversity of shell species. In the intertidal region of Grande Beach, Brazil, Clibanarius antillensis has been reported to occupy 13 types of gastropod shells (Turra and Leite, 2001), while this same species occupies 41 shell species in Montepio, Veracruz, México (Argüelles, 2004). Grouping shells according to their morphology could be a way to better understand the shell pattern occupancy in high diversity areas.

\section{ACKNOWLEDGEMENTS}

E. Naranjo is thanked for helping in the identification of the malacological material, J.L. Villalobos and K. Kruesi for their assistance in the field. Thanks are also due to the Estación de Biología Tropical Los Tuxtlas, UNAM. This study was funded by the programmes PAPIIT-UNAM (IN-211106, IN-208702). 


\section{REFERENCES}

Abbott, R.T. and P.A. Morris. - 1995. A field guide to shells of the Atlantic and Gulf Coasts and West Indies. Houghton Mifflin Company, Boston.

Abele, L.G. and W. Kim. - 1986. An illustrated guide to the marine Decapod Crustaceans of Florida. Dept. Environ. Reg. Tech Ser. 8: 1-760.

Alcaraz, G. and K. Kruesi. - 2009. The role of previous shell occupancy in the wild on laboratory shell choice by hermit crab Calcinus californiensis. Mar. Fresh. Behav. Physiol., 42(1): 55-62.

Andrews, J. - 1971. Seashells of the Texas Coast. University of Texas Press, London.

Argüelles, A. - 2004. Uso diferencial de conchas de gasterópodos por cangrejos ermitaños en respuesta a la acción del oleaje en una costa rocosa. MSc thesis, Univ. Nacional Autónoma de México, México.

Bell, E.C. and J.M. Gosline. - 1997. Strategies for life in flow: tenacity, morphometry, and probability of dislodgement of two Mytilus species. Mar. Ecol. Prog. Ser., 15: 197-208.

Bertness, M.D. - 1981a. Interference, exploitation, and sexual components of competition in a tropical hermit crab assemblage. $J$. Exp. Mar. Biol. Ecol., 49: 189-202.

Bertness, M.D. - 1981b. Predation, physical stress, and the organization of a tropical rocky intertidal hermit crab community. Ecology, 62: 411-425.

Bollay, M. - 1964. Distribution and utilization of gastropod shells by the hermit crabs Pagurus samuelis, Pagurus granosimanus, and Pagurus hirsutiusculus at Pacific Grove, California. Veliger, 6: $71-76$.

Borjesson, D.L. and W.A. Szelistowski. - 1998. Shell selection and predation in the hermit crab Clibanarius panamensis Stimpson in a tropical mangrove estuary. J. Exp. Mar. Biol. Ecol., 133: 213-228.

Carrington, E.B. and M.W. Denny. - 1994. Quantifying "wave exposure": a simple device for recording maximum velocity and results of its use at several field sites. J. Exp. Mar. Biol. Ecol., 181: 9-29.

Childress, J.R. - 1972. Behavioral ecology and fitness theory in a tropical hermit crab. Ecology, 53: 960-964.

Connell, J.H. - 1972. Community interactions on marine rocky in tertidal shores. Annu. Rev. Ecol. Syst., 3: 169-192.

Conover, M.R. - 1978. The importance of various shell characteristics to the shell- selection behavior of hermit crabs. J. Exp. Mar. Biol. Ecol., 32: 131-142.

Côté, I.M., B. Reverdy and P.K. Cooke. - 1998. Less choosy or different preference? Impact of hypoxia on hermit crab shell assessment and selection. Anim. Behav., 56: 867-873.

Denny, M.W. and S.D. Gaines. -1990 . On the prediction of maximal wave forces. Limnol. Oceanogr., 35: 1-15.

Denny, M.W., T.L. Daniel and M.A.R. Koehl. - 1985. Mechanical limits to size in wave-swept organisms. Ecol. Monogr., 55: 69-102.

Floeter, S.R., R.C. Nalesso, M.M.O. Rodrigues and A. Turra -2000 . Patterns of shell utilization and selection in two sympatric hermit crabs (Anomura: Diogenidae) in south-eastern Brazil J. Mar. Biol. Ass. U.K., 80: 1053-1059.

Fotheringham, N. - 1976. Population consequences of shell utilization by hermit crabs. Ecology, 57: 570-578.

Frankovich, T.A. and J.C. Zieman. - 2005. A temporal investigation of grazer dynamics, nutrients, seagrass leaf productivity, and epiphyte stock. Estuaries, 28: 41-52.

García, R.B. and F.L.M. Mantelatto. - 2001. Shell selection by the tropical hermit crab Calcinus tibicen (Herbst, 1791) (Anomura, Diogenidae) from Southern Brazil. J. Exp. Mar. Biol. Ecol., 265: 1-14.

García-Cubas, A., M. Reguero and L. Jácome. - 1994. Moluscos arrecifales de Veracruz México. UNAM, México.

García-March J.R., L. Pérez-Rojas and A.M. García-Carrascosa. - 2007. Influence of the hydrodynamic forces on population structure of Pinna nobilis L., 1758 (Mollusca: Bivalvia): The critical combination of drag force, water depth, shell size and orientation. J. Exp. Mar. Biol. Ecol., 342: 202-212.
Hahn, D.R. - 1998. Hermit crab shell use patterns: response to previous shell experience and to water flow. J. Exp. Mar. Biol. Ecol., 228: 35-51.

Hazlett, B.A. - 1980. Communication and mutual resource exchange in north Florida hermit crabs. Behav. Ecol. Sociobiol., 6: $177-184$.

Hazlett, B.A. - 1981. The behavioral ecology of hermit crabs. Annu. Rev. Ecol. Syst., 12: 1-22.

Hazlett, B.A. - 1989. Mating success of male hermit crabs in shell generalist and shell specialist species. Behav. Ecol. Sociobiol., 25: 119-128.

Hernández, M.C. and F. Alvarez. - 2007. Changes in the crustacean community of a tropical rocky intertidal shore: is there a pattern? Hidrobiologica, 17: 25-34.

Lau, W.W.Y and M.M. Martinez. - 2003. Getting a grip on the intertidal: flow microhabitat and substratum type determine the dislodgement of the crab Pachygrapsus crassipes (Randall) on rocky shores and estuaries. J. Exp. Mar. Biol. Ecol., 295: 1-21.

Lively, C.M. - 1989. The effects of shell mass, surface topography, and depth for withdrawal on shell selection by an intertidal hermit crab. Mar. Behav. Physiol., 14: 161-168.

Markham, J.C. - 1968. Notes on growth-patterns and shell-utilization of the hermit crab Pagurus bernhardus (L). Ophelia, 5: 189-205.

Palmer, M.A. - 1988. Epibenthic predators and marine meiofauna: separating predation, disturbance, and hydrodynamic effects. Ecology, 69: 1251-1259.

Pérez, R.R. - 1997. Moluscos de la plataforma continental. UAM, México.

Powers, S.P. and J.N. Kittinger. - 2002. Hydrodynamic mediation of predator-prey interactions: differential patterns of prey susceptibility and predatory success explained by variation in water flow. J. Exp. Mar. Biol. Ecol., 273: 171-187.

Prieto, A., S. Sant, E. Méndez and C. Lodeiros. - 2003. Diversity and abundance of mollusks in Thalassia testudinum prairies of the Bay of Mochima, Mochima National Park, Venezuela. Rev. Biol. Trop., 51: 413-426.

Provenzano, A.J. - 1959. The shallow-water hermit crabs of Florida. Bull. Mar. Sci., 9: 349-420.

Raimondi, P.T. and C.M. Lively. - 1986. Positive abundance and negative distribution effects of a gastropod on an intertidal hermit crab. Oecologia, 69: 213-216.

Reese, E.S. - 1962. Shell selection behavior of hermit crabs. Anim. Behav., 10: 347-360.

Reese, E.S. - 1969. Behavioral adaptations of intertidal hermit crabs. Am. Zool., 9: 343-355.

Rittschof, D., J. Sarrica and D. Rubenstein. - 1995. Shell dynamics and microhabitat selection by striped legged hermit crab, Clibanarius vittatus (Bosc). J. Exp. Mar. Biol. Ecol., 192: 157-172.

Scully, E.P - 1979. The effects of gastropod shell availability and habitat characteristics on shell utilization by the intertidal hermit crab Pagurus longicarpus Say. J. Exp. Mar. Biol. Ecol., 37: 139-152.

Servicio Mareográfico Nacional. Instituto de Geofísica, Universidad Nacional Autónoma de México (http://mareografico.unam.mx).

Turra, A. and F.P.P. Leite. - 2001. Shell utilization patterns of a tropical rocky intertidal hermit crab assemblage: I. The case of Grande Beach. J. Crustac. Biol., 21: 393-406.

Vance, R.R. - 1972a. Competition and mechanism of coexistence in three sympatric species of intertidal hermit crabs. Ecology, 53: $1062-1074$

Vance, R.R. - 1972b. The role of shell adequacy in behavioral interactions involving hermit crabs. Ecology, 53: 1075-1083.

Vogel, S. 1988. Life's devices. The physical world of animals and plants. Princeton University Press, Oxford.

Wilson, E.A., E.N. Powell and S.M. Ray. - 1991. The effects of host density and parasite crowding on movement and patch formation of the ectoparasitic snail, Boonea impressa: field and modeling results. J. Anim. Ecol., 60: 779-804.

Wye, K.R. - 2000. The Encyclopedia of shells. Chartwell Books, Inc., New Jersey.

Scient. ed.: C. Zeng

Received June 12, 2008. Accepted February 2, 2009.

Published online July 10, 2009. 